\title{
Kanser Hastalarında Umutsuzluk ve Manevi Bakım Algısının Değerlendirilmesi
}

\section{Assessment of Hopelessness and Spiritual Care Perception in Cancer Patients}

\author{
(D) Gülden Atan'1, (1) Zülfünaz Özer², (1) Gülcan Bahçecioğlu Turan³

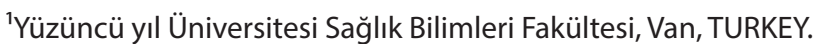 \\ ${ }^{2}$ Istanbul Sabahattin Zaim Üniversitesi, Sağlık Bilimleri Fakültesi,Istanbul,TURKEY. \\ ${ }^{3}$ Fırat Üniversitesi, Sağlık Billimleri Fakültesi, Elazığ, TURKEY
}

\section{Öz}

Amaç: Bu çalışma, kanser hastalarında umutsuzluğun ve manevi bakım algısının değerlendirilmesi amacıyla tanımlayıcı ve kesitsel olarak yapıldı.

Gereç ve Yöntem: Bu çalışmanın evrenini, Haziran - Eylül 2019 tarihleri arasında bir üniversite hastanesinin onkoloji servisinde tedavi gören tüm kanser hastaları oluşturdu. Araştırmanın örneklemini ise, kanser hastalığı olup araştırmaya katılmayı engelleyebilecek fiziksel ve zihinsel bir problemi bulunmayan, araştırmaya katılmayı gönüllü olarak kabul eden, soruları yanıtlayabilecek bilişsel yeterliliği sahip, 18 yaş ve üzerinde olan 125 hasta oluşturdu. Veriler araştırmacılar tarafından yüz yüze görüşme tekniği ile "Kişisel Bilgi Formu", " BECK Umutsuzluk Ölçeği" ve "Maneviyat ve Manevi Bakım Dereceleme Ölçeği" kullanılarak toplandı

Bulgular: Hastaların BECK Umutsuzluk Ölçeği puan ortalaması $11,63 \pm 5,34$, maneviyat ve manevi bakım ölçeği puan ortalaması $66,54 \pm 4,90$ olarak saptandı. Hastaların yaşı ile gelecek ile ilgili duygular puanı arasında anlamlı, pozitif bir ilişki olduğu görüldü $(r=0,183$ ve $p=0,041)$. Bekar hastalarla farklı bir kronik hastalığı olanların BUÖ toplam puan ortalamasının, gelecek ile ilgili duygular puan ortalamasının ve gelecek ile ilgili beklentiler puan ortalamasının daha yüksek olduğu saptandı. Katılımcılardan bekar olan, ailesinde başka kanser hastası olan ve farklı bir kronik hastalığı olan hastaların maneviyat ve manevi bakım dereceleme ölçeğitoplam puan ortalaması daha yüksek bulundu $(p<0,05)$. Ayrıca araştırmaya dahil edilen hastaların maneviyat ve manevi bakım algılarıyla umutsuzluk düzeyleri arasında istatistiksel olarak anlamlı ve doğrusal bir ilişki olmadığı sonucuna varıldı $(p>0,05)$.

Sonuç: Kanser hastaların orta düzeyde umutsuzluğa sahip olduğu belirlendi. Hastaların maneviyat ve manevi bakım algıların yüksek düzeyde olduğu bulundu.

Anahtar Kelimeler: Kanser, manevi bakım, umutsuzluk

\begin{abstract}
Aims: This study was conducted descriptively and cross-sectionally to evaluate hopelessness and spiritual care perceptions of cancer patients

Material and Method: The population of this study consisted of all cancer patients treated in an oncology department of a university hospital between June and September 2019. The sample of the study consisted of 125 patients who were 18 years or older, who had cancer and had no physical and mental problems that could prevent participation in the study, voluntarily accepted to participate in the study, and had cognitive competence to answer the questions. Data were collected by researchers using the "Personal Information Form", "BECK Hopelessness Scale" and "Spirituality and Spiritual Care Rating Scale" by face to face interview technique.

Results: Patients' BECK Hopelessness Scale score average was determined to be $11.63 \pm 5.34$ and spirituality and spiritual care scale score average was $66.54 \pm 4.90$. There was a positive relation between patients' age and their emotions about the future score $(r=0.183$ and $\mathrm{p}=0.041$ ). Beck hopelessness total score average, emotions about the future score average and expectations about the future score average were found to be higher in single patients and patients with a different chronic disease. Spirituality and spiritual care graduation scale total score average was found to be higher in single participants, participants with other cancer patients in the family and participants with another chronic disease $(p<0.05)$. Also it was determined that there was no significant and linear relationship between spirituality and spiritual care perception and hopelessness levels of the patients participated in the study ( $p>0.05)$.

Conclusions: Cancer patients had moderate hopelessness. Spiritual and spiritual care perceptions of the patients were found to be high.
\end{abstract}

Keywords: Cancer, hopelessness, spiritual care,

Corresponding (illetişim): Gülden ATAN, Yüzüncü Yıl Üniversitesi Sağlık Bilimleri Fakültesi, Van, TURKEY 


\section{GíRiş}

Kanser; psikolojik, sosyal, fiziksel ve manevi boyutları etkileyerek birden fazla belirtiyi içeren, tanı konulduğu andan itibaren uzun vadede tedavi ve bakım gerektiren, dünyada ve ülkemizde görülme sıklığı hızla artan evrensel bir sağlık sorunudur. ${ }^{[1,2]}$ Kanser, yirminci yüzyılın ilk yarısında ölüme sebep olan hastalıklarda sekizinci sırada iken, günümüzde kardiyovasküler hastalıklardan sonra ikinci sırada yer almaktadır. ${ }^{[3]}$

Kanser hastaları, tanı, tedavi ve palyasyon dönemlerinde belirsizlikle birlikte oldukça yoğun duygusal, ruhsal ve davranışsal problemler yaşamaktadırlar. ${ }^{[4]} \mathrm{Bu}$ problemler nedeniyle kanser hastası olan birey umutsuzluk yaşayabilmektedir. ${ }^{[5]}$ Umutsuzluk, bireyin sorunlarını çözmek ya da istediği şeyleri yapabilmek için kişisel herhangi bir seçeneğinin olmadığı ya da amaçlarına ulaşabilmek için kendi enerjisini açığa çıkartamadığı duygusal bir durum olarak ifade edilmektedir. ${ }^{[6]}$ Umut; kanser hastalarının pozitif yaşam enerjisine katkıda bulunmakta, hastalık ve kayıp süresini iyileştirmekte, çaresizlik, belirsizlik ve karamsarlık gibi duyguları önlemekte ve bireylerin hastalık süreciyle daha iyi baş etmelerine, uyumlarına ve iyilik hallerinin sürdürülmesine olanak sağlamaktadır. ${ }^{[7]}$ Yapılan çalışmalarda umut düzeyi yüksek olan hastaların prognozlarının daha iyi ve yaşam kalitelerinin daha yüksek olduğu saptanmıştır. ${ }^{[8,9]}$ Ayrıca kanser hastalarında umudun psikolojik huzursuzluğu azaltıp, daha iyi ağrı kontrolü sağladığı ve ağrının şiddetini azalttığı bildirilmektedir. ${ }^{[10]}$ Kanser hastaların umut düzeylerinin belirlenmesi ve umudu destekleyen bir hemşirelik bakımının geliştirilmesi oldukça önemli bulunmaktadır. Bakım sürecinin her aşamasında olduğu gibi tedavi sırasında da umudun kanser hastalarına güç verdiği, psikolojik destek sağlayıp onları motive ettiği, tedavinin yan etkilerini azalttığı, hastalık sürecine ve tedaviye uyumlarını artırarak daha kaliteli bir bakım süreci sağladığı bildirilmektedir. ${ }^{[1]]}$

Kansere bağlı olarak ortaya çıkan psikososyal sorunlar holistik bakım anlayışı ile ele alınması gerekmektedir. ${ }^{[12]}$ Holistik bakıma göre birey; bedensel, sosyokültürel, mental, emosyonel ve spritüel boyutlarıyla bir bütün olup, bu boyutlar birbirleri ile ilişkili bulunmaktadır. Holistik bakımın sağlık hizmetlerinde sunulmaya başlanması ile birlikte bireylerin manevi boyutu önem kazanmıştır. ${ }^{[13]}$ Modern hemşireliğin kurucusu olan Florence Nightingale de bireylerin sağlığı için manevi gereksinimlerin, fiziksel organlar kadar önemli olduğunu vurgulayarak maneviyatın holistik bir bakım sunulmasındaki önemine dikkat çekmiştir. ${ }^{[14]}$

Türk Dil Kurumu maneviyatı; "maddi olmayan manevi şeyler (görülmeyen, duyularla sezilebilen, soyut, tinsel)" şeklinde açıklamıştır. ${ }^{[15]}$ Hemşirelik literatüründeki en geniş tanımıyla maneviyat; herhangi bir dini bağlıı̆ın dışında, bireyin hiçbir tanrısal inancı olmadan hayatın anlamı ve amacı için iç huzuru sağlamak amacıyla çaba harcamak şeklinde tanımlanmaktadır. ${ }^{[16]}$ Maneviyat; bireylerin hastalıklarla baş etmesinde, iyilik halinin sağlanmasında, kronik hastalıkların tedavi ve iyileşme sürecinde etkin bir rol oynamaktadır. ${ }^{[17,18]}$ Ayrıca maneviyatın kanser hastalarında, hastalık esnasında ruh sağlığına pozitif bir etkisi olduğu belirtilmektedir. ${ }^{[19]}$ Yapılan bir araştırmada maneviyatın sağılık, iyilik ve yaşam kalitesi üzerinde belirgin etkisi olduğu belirtilmekle birlikte, hastalıkların iyileşmesinde de önemli bir yeri olduğu vurgulanmaktadır. ${ }^{[20]}$ Johnson ve ark. [22] (2011) manevi inancı yüksek olan hastaların umut düzeylerinin daha yüksek olduğunu saptamışlardır. Farklı bir çalışmada ise, maneviyat düzeyi yüksek onkolojik hastalarının, maneviyat düzeyi düşük olan hastalara oranla psikolojik açıdan daha iyi durumda oldukları, daha iyimser oldukları, buna karşılık daha az stres ve kaygı yaşadıkları, daha umutlu olup, daha az intihara teşebbüs ettikleri belirtilmiştir.

Hemşirelik, hastaların umutları ve korkuları hakkında konuşmalarını dinlemek için ayrıcalıklı bir meslek olarak ifade edilmiştir. Onkolojik hastaların bakım ve tedavi sürecinde, hastaların bireysel özellikleri dikkate alınarak bütüncül olarak değerlendirilmelidir. ${ }^{[23]} \mathrm{Bu}$ bilgiler ışığında onkoloji hastalarında, maneviyat ve umut ile ilişkisini araştırmalarla ortaya koymak ve holistik bakımının sunumunda önemli rolleri bulunan hemşirelerin bu konudaki farkındalıklarını arttırmak son derece önemli olduğu bildirilmiştir. ${ }^{[13]} \mathrm{Bu}$ çalışma, kanser hastalarında umutsuzluğun ve manevi bakım algısının değerlendirilmesi amacıyla yapılmıştır.

\section{GEREÇ VE YÖNTEM}

\section{Araştırmanın Yeri ve Özellikleri}

Kesitsel tanımlayıcı tipteki bu çalışma bir üniversite hastanesinin onkoloji kliniğinde tedavi gören kanser hastalarının umutsuzluk düzeylerini ve manevi bakım algılarını incelemek amacıyla gerçekleştirildi.

\section{Araştırmanın Evreni ve Örneklemi}

Araştırmanın evrenini, Haziran - Eylül 2019 tarihleri arasında bir üniversite hastanesinin onkoloji servisinde tedavi gören tüm kanser hastaları oluşturdu. Araştırmanın örneklemini ise, kanser hastalığı olup araştırmaya katılmayı engelleyebilecek fiziksel ve zihinsel bir problemi bulunmayan, araştırmaya katılmayı gönüllü olarak kabul eden, soruları yanıtlayabilecek bilişsel yeterliliği sahip, 18 yaş ve üzerinde olan 125 hasta oluşturdu.

\section{Veri toplama araçları}

Veriler araştırmacılar tarafından yüz yüze görüşme tekniği ile "Kişisel Bilgi Formu", " BECK Umutsuzluk Ölçeği" ve "Maneviyat ve Manevi Bakım Dereceleme Ölçeği" kullanılarak toplandı.

Kişisel Bilgi Formu: Araştırmacılar tarafından geliştirilen bu form hastaların cinsiyet, yaş, medeni durum, eğitim durumu, aile tipi, çalışma durumu ve ailede başka kanser hastasının varlığı gibi demografik özellikleri içeren sorular ile hastalık tanısı, hastalık süresi ve başka bir kronik hastalığın varlığı gibi hastalıkla ilgili özellikleri içeren sorulardan oluşmaktadır.

BECK Umutsuzluk Ölçeği (BUÖ): Beck tarafından 1974 yılında geliştirilen bu ölçeğin Türkçe geçerlilik ve güvenilirlik çalışmasını 1991 yılında Seber ve 1994 yılında ise Durak 
\& Palabıyıkoğlu yapmıştır. ${ }^{[24-26]}$ Bireyin geleceğe yönelik beklentilerini ve karamsarlık düzeyini ölçmeyi amaçlayan 20 maddeli bir ölçektir. Ölçekte gelecekle ilgili duyguları içeren maddeler "1, 6.9.13.15"; güdü kaybı ile ilgili maddeler "2.3.9.11.12.16.17.20"; gelecek beklentisiyle ilgili maddeler "4.7.14.18" olarak belirlenmiştir. On bir "doğru", dokuz "yanlış" yanıtı içeren ölçek anahtarlarına göre, her uyumlu yanıt için "1", uyumsuz yanıt için " 0 " puan verilmektedir. Elde edilen "aritmetik" toplam "umutsuzluk" puanını oluşturmaktadır. BUÖ den alınabilecek 0-3 puan umutsuzluğun olmadığını, 4-8 hafif umutsuzluk, 9-14 orta derecede umutsuzluk ve 15 ve üstü ciddi umutsuzluk olduğunu göstermektedir. ${ }^{[26]}$ Ölçeğin geçerlilik güvenirlik çalışmasında Cronbach Alpha değeri 0,86 olarak bildirilmiştir. ${ }^{[25]}$ Çalışmamızda ölçeğin Cronbach alfa değeri 0,94 olarak bulundu.

Maneviyat ve Manevi Bakım Dereceleme Ölçeği (MMBDÖ): McSherry ve ark..$^{[27]}$ tarafından maneviyat ve manevi bakım kavramlarının algılanma düzeyini değerlendirmek amacıyla geliştirilmiş 17 maddeli üç boyutlu bir ölçektir.Ergül ve Temel tarafından ölçeğin Türkçe geçerlilik ve güvenirliği yapılmıştır. ${ }^{[28]}$ Beşli likert tipli bir ölçek olup ölçekteki maddeler "1-Kesinlikle Katılmıyorum, 2- Katılmıyorum, 3- Kararsızım, 4- Katılıyorum ve 5- Tamamen Katılıyorum" şeklinde puanlanmaktadır "3., 4., 13. ve 16." Maddeler ise ters puanlanmaktadır. Ölçek puanlamasında kesme noktası bulunmamaktadır. Ölçek "maneviyat ve manevi bakım (6., 7., 8., 9., 11., 12., ve 14 maddeler)", "bireysel bakım (1., 2., 10. ve 15 ". maddeler )" ve "dinsellik (4., 5., 13. ve 16 maddeler )" alt boyutlarından oluşmaktadır. Ölçek üç boyutlu olmasına karşın değerlendirmede alt boyutları dikkate alınmamaktadır. Ölçekten alınabilecek en yüksek puan 69 olup puanın yüksek olması maneviyat ve manevi bakım algılarının pozitif yönde yüksek olduğunu göstermektedir. Ölçeğin Cronbach alfa değeri 0,76 olarak verilmiştir. ${ }^{[28]}$ Çalışmamızda ölçeğin Cronbach alfa değeri 0,41 olarak bulundu.

\section{Verilerin Değerlendirilmesi}

Araştırma sonucunda elde edilen verilerin değerlendirilmesi bilgisayar ortamında SPSS 25 paket programında yapıldı. Değişkenlere ilişkin tanımlayıcı istatistikler sayı, yüzdeler, aritmetik ortalama ve standart sapma olarak verildi. Sayısal değişkenlerin (yaş, kullanılan ölçek genel ve alt boyut puanları) normallikleri Kolmogorov Smirnov testi ile kontrol edildi. Veriler Independent Samples t test, Mann Whitney $\mathrm{U}$ testi, ANOVA testi, Kruskall Wallis, Pearson Korelasyon Katsayısı kullanılarak değerlendirildi. kullanıldı. Elde edilen bulgular \%95 güven aralığında, \%5 anlamlılık düzeyinde değerlendirildi.

\section{Araştırmanın Etik ilkeleri}

Araştırma Van Yüzüncü yıl Üniversitesi Klinik Araştırmalar Etik Kurulu'ndan 15/05/2019 tarih 2019/05-01 sayı ile onay ve araştırmanın gerçekleştirildiği kurumdan yazılı izin alındı. Ayrıca araştırmaya katılan bireylerden de araştırmanın amacı açıklandıktan sonra sözlü onam alındı. Ölçeklerin geçerlik ve güvenirlik çalışmasını yapan yazarlarından yazılı izin alındı.

\section{BULGULAR}

Tablo 1'de araştırmaya dahil edilen hastaların sosyodemografik ve hastalıkla ilgili bilgileri incelendi. Araştırmaya dahil edilen 125 hastanın \%56'sı erkek ve yaş ortalaması $57,91 \pm 13,92$ olarak saptandı. Eğitim durumları incelendiğinde; \%48'i okur yazar değil iken \%33,6'sının ilköğretim, \%14,4'ünün lise ve \%4'ünün ise üniversite ve üzeri olduğu görüldü.

\begin{tabular}{|c|c|c|c|}
\hline & & $\mathbf{n}$ & $\%$ \\
\hline \multirow{2}{*}{ Cinsiyet } & Kadın & 55 & 44 \\
\hline & Erkek & 70 & 56 \\
\hline \multirow{4}{*}{ Eğitim Durumu } & Okur yazar değil & 60 & 48 \\
\hline & İlköğretim & 42 & 33,6 \\
\hline & Lise & 18 & 14,4 \\
\hline & Üniversite ve üzeri & 5 & 4 \\
\hline \multirow{2}{*}{ Medeni Durum } & Evli & 70 & 56 \\
\hline & Bekar & 55 & 44 \\
\hline \multirow{2}{*}{ Çalışma Durumu } & Çalışıyor & 7 & 5,6 \\
\hline & Çalışmıyor & 118 & 94,4 \\
\hline \multirow{3}{*}{ Biriyle Yaşama Durumu } & Yalnız & 38 & 30,4 \\
\hline & Eşim ile & 65 & 52 \\
\hline & Akrabalarım ile & 22 & 17,6 \\
\hline \multirow{2}{*}{ Sosyal destek Durumu } & Evet & 56 & 44,8 \\
\hline & Hayır & 69 & 55,2 \\
\hline \multirow{2}{*}{$\begin{array}{l}\text { Ailede Başka Kanser } \\
\text { Hastasının Olma Durumu }\end{array}$} & Evet & 90 & 72 \\
\hline & Hayır & 35 & 28 \\
\hline \multirow{12}{*}{ Klinik Tanı } & Mide kanseri & 33 & 26,4 \\
\hline & Kolon kanseri & 20 & 16 \\
\hline & Akciğer kanseri & 14 & 11,2 \\
\hline & Meme kanseri & 11 & 8,8 \\
\hline & Lenf kanseri & 9 & 7,2 \\
\hline & Pankreas kanseri & 7 & 5,6 \\
\hline & Gırtlak kanseri & 7 & 5,6 \\
\hline & Over kanseri & 6 & 4,8 \\
\hline & Testis kanseri & 6 & 4,8 \\
\hline & Cilt kanseri & 6 & 4,8 \\
\hline & Prostat kanseri & 3 & 2,4 \\
\hline & Rahim kanseri & 3 & 2,4 \\
\hline \multirow{4}{*}{ Hastalık Süresi } & $0-6$ ay & 17 & 13,6 \\
\hline & 7 ay-1 yıl & 62 & 49,6 \\
\hline & $2-5 \mathrm{yll}$ & 44 & 35,2 \\
\hline & 5 yıl ve üzeri & 2 & 1,6 \\
\hline \multirow{2}{*}{$\begin{array}{l}\text { Farklı Kronik Hastalık } \\
\text { Durumu }\end{array}$} & Evet & 76 & 60,8 \\
\hline & Hayır & 49 & 39,2 \\
\hline \multirow{4}{*}{ Farklı Kronik Hastalık } & Diyabet & 15 & 19,74 \\
\hline & Kr. Gastrit & 16 & 21,05 \\
\hline & Hipertansiyon & 28 & 36,84 \\
\hline & Astım & 17 & 22,37 \\
\hline Yaş ortalaması (Ort \pm SS) & $57,91 \pm 13,92$ & & \\
\hline
\end{tabular}

Tablo 2. incelendiğinde araştırmadaki hastaların MMBDÖ puan ortalamasının $66,54 \pm 4,90$ olduğu görülmektedir. Araştırmadaki hastaların BUÖ puan ortalamasının ise $11,63 \pm 5,34$ olduğu saptandı. 
Tablo 2. Hastaların MMBDÖ ve BUÖ Puan Ortalamalar

\begin{tabular}{|lcccc|}
\hline & Ort. & SS & Min. & Maks. \\
\hline BUÖ- Toplam & 11.63 & 5.34 & 2.00 & 20.00 \\
Gelecek ile ilgili duygular & 3.26 & 1.89 & 0.00 & 5.00 \\
Motivasyon kaybı & 4.04 & 2.20 & 0.00 & 8.00 \\
Gelecek ile ilgili beklentiler & 3.47 & 1.46 & 0.00 & 5.00 \\
MMBDÖ- Toplam & 66.54 & 4.90 & 46.00 & 75.00 \\
\hline
\end{tabular}

Araştırmaya katılan hastaların yaşı ile gelecek ile ilgili duygular puanı arasında anlamlı, doğrusal, aynı yönlü ve zayıf bir ilişki olduğu görüldü ( $r=0,183$ ve $p=0,041)$. Yaş ile BUÖ, motivasyon kaybı, gelecek ile ilgili beklentiler ve MMBDÖ puanları arasında istatistiksel olarak anlamlı bir ilişki bulunamadı (her biri için $p>0,05)$.
Araştırmaya dahil edilen hastaların medeni durumlarına ve farklı bir kronik hastalığın olmasına göre gelecek ile ilgili duygular puan ortalamaları arasında istatistiksel olarak anlamlı fark olduğu tespit edildi; buna göre bekar hastaların ve farkı bir kronik hastalığı olanların gelecek ile ilgili duygular puan ortalaması anlamlı düzeyde yüksek bulundu. Ayrıca bireylerin kiminle yaşadıklarına göre gelecek ile ilgili duygular puan ortalamalarıarasındaki farkın da anlamlıolduğu; bu farkın yalnızeşim ile ikilisinden kaynaklandığı ve yalnız yaşayan bireylerin gelecek ile ilgili duygular puan ortalaması, eşi ile yaşayanlara göre daha yüksek olduğu görüldü. Yine araştırmaya dahil edilen bireylerin hastalık teşhis zamanı bakımından gelecek ile ilgili duygular puan ortalamaları incelendiğinde; 7 ay-1 yıl ve 2-5 yıl sürede teşhis konulan bireylerin gelecek ile ilgili duygular puan ortalaması, 0-6 ayda teşhis konulan bireylere göre anlamlı düzeyde yüksekti (Tablo 3, her biri için $p<0,05$ ).

Tablo 3. Hastaların Demografik ve Bazı Klinik Bilgileri Bakımından BUÖ Toplam ve Alt Boyut Puanlarının Karşılaştırılması.

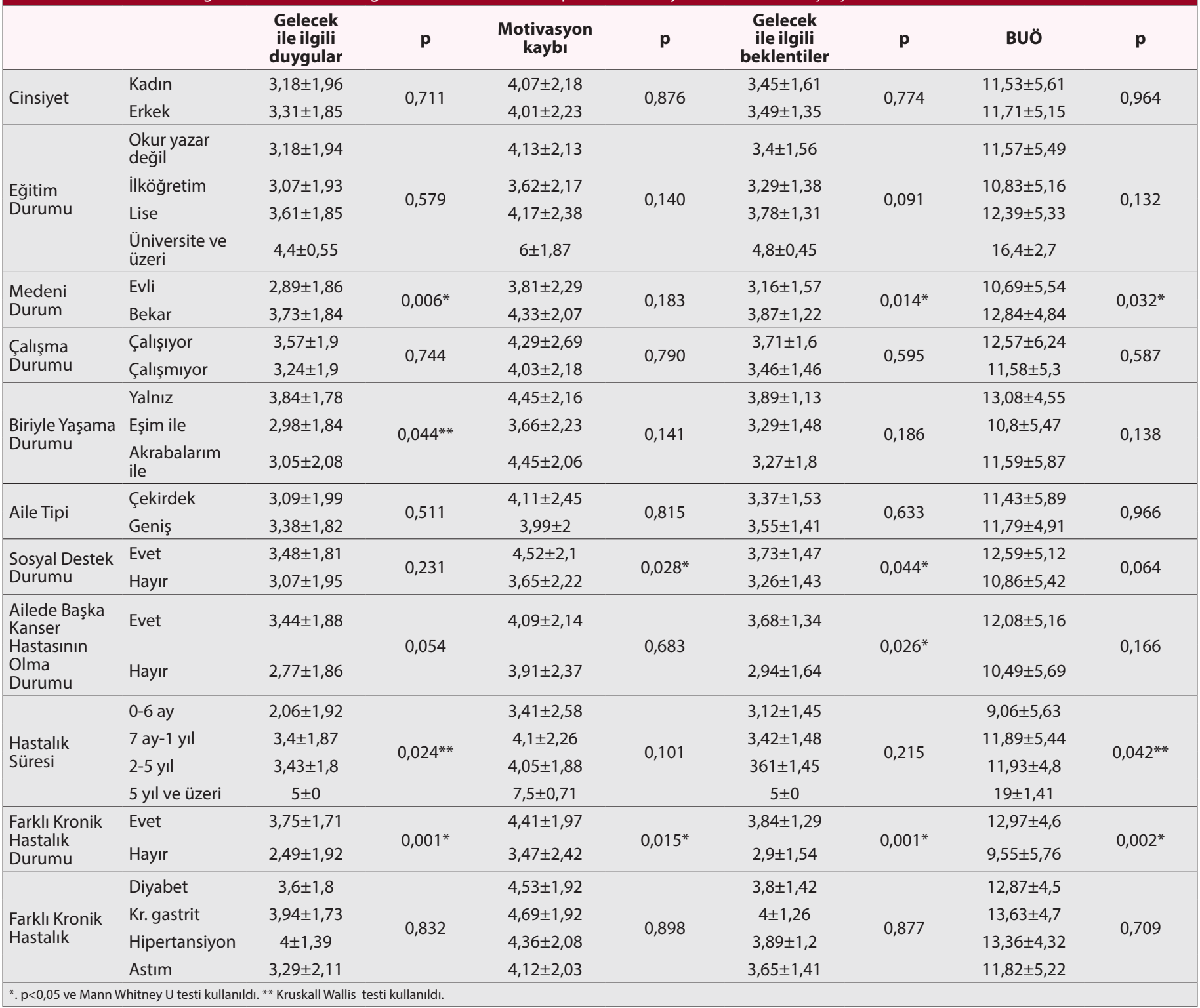


Araştırmaya dahil edilen hastalarda sosyal desteği olanların, farklı bir kronik hastalığı bulunanların motivasyon kaybı puan ortalamaları arasında istatistiksel olarak anlamlı fark olduğu tespit edildi. Katılımcılarından bekar olanların, sosyal desteği olan, farklı bir kronik hastalığı olan ve ailesinde başka kanser hastası olan hastaların gelecek ile ilgili beklentiler puan ortalaması anlamlı düzeyde daha yüksek olduğu saptandı (Tablo 3, her biri için $p<0,05$ ).

Araştırmaya katılan bekar olan ve farklı bir kronik hastalığı olan bireylerin BUÖ puan ortalaması anlamlı düzeyde daha yüksek olduğu saptandı. Aynı şekilde bireylerin hastalık teşhis zamanı bakımından BUÖ puan ortalamaları arasında istatistiksel olarak anlamlı fark olduğu; buna göre teşhis zamanı 5 yıl ve üzeri olan bireylerin BUÖ puan ortalaması, teşhis zamanı 0-6 ay, 7 ay- 1 yıl ve 2-5 yıl olan bireylere göre daha yüksek olduğu tespit edildi (Tablo 3, her biri için $p<0,05$ ). Diğer karşılaştırmalar da ise istatistiksel olarak anlamlı bulgulara rastlanmadı (Tablo 3, her biri için $p>0,05$ ).

Katılımcılardan bekar olan, ailesinde başka kanser hastası olan ve farklı bir kronik hastalığı olan hastaların maneviyat ve manevi bakım dereceleme ölçeği-toplam puan ortalaması anlamlı düzeyde daha yüksek bulundu (Tablo 4, her biri için $p<0,05$ ). Diğer karşılaştırmalar incelendiğinde herhangi bir anlamlı farklılık bulunamadı (Tablo 4, her biri için $\mathrm{p}>0.05$ ).

Araştırmaya dahil edilen hastaların maneviyat ve manevi bakım algılarıyla umutsuzluk düzeyleri arasında istatistiksel olarak anlamlı ve doğrusal bir ilişki olmadığı sonucuna varıldı $(p>0,05)$.

\begin{tabular}{|c|c|c|c|}
\hline & & $\begin{array}{l}\text { MMBDÖ } \\
\text { Toplam }\end{array}$ & $\mathbf{p}$ \\
\hline \multirow{2}{*}{ Cinsiyet } & Kadın & $66,71 \pm 4,54$ & \multirow{2}{*}{0,850} \\
\hline & Erkek & $66,4 \pm 5,2$ & \\
\hline \multirow{4}{*}{ Eğitim durumu } & Okuryazardeğil & $67,13 \pm 4,82$ & \multirow{4}{*}{0,455} \\
\hline & Illköğretim & $66,57 \pm 3,74$ & \\
\hline & Lise & $64,5 \pm 6,9$ & \\
\hline & Üniversiteveüzeri & $66,4 \pm 5,81$ & \\
\hline \multirow{2}{*}{ Medeni durum } & Evli & $65,79 \pm 4,87$ & \multirow{2}{*}{$0,016^{*}$} \\
\hline & Bekar & $67,49 \pm 4,83$ & \\
\hline \multirow{2}{*}{ Çalışma durumu } & Çalışıyor & $65,14 \pm 9,89$ & \multirow{2}{*}{0,525} \\
\hline & Çalışmıyor & $66,62 \pm 4,51$ & \\
\hline \multirow{4}{*}{ Biriyle Yaşama Durumu } & Yalnız & $66,95 \pm 5,25$ & \multirow{4}{*}{0,334} \\
\hline & Eşimile & $66 \pm 5$ & \\
\hline & Akrabalarımile & $67,41 \pm 3,9$ & \\
\hline & Geniş & $67,41 \pm 3,99$ & \\
\hline \multirow{2}{*}{ Sosyal Destek Durumu } & Evet & $66,77 \pm 4,81$ & \multirow{2}{*}{0,645} \\
\hline & Hayır & $66,35 \pm 5,01$ & \\
\hline \multirow{2}{*}{$\begin{array}{l}\text { Ailede Başka Kanser } \\
\text { Hastasının Olma Durumu }\end{array}$} & Evet & $67,37 \pm 3,97$ & \multirow{2}{*}{$0,021^{*}$} \\
\hline & Hayır & $64,4 \pm 6,33$ & \\
\hline \multirow{4}{*}{ Hastalık Süresi } & 0 -6ау & $63,47 \pm 7,26$ & \multirow{4}{*}{0,112} \\
\hline & 7ay-1yıl & $66,6 \pm 4,8$ & \\
\hline & $2-5 y ו 1$ & $67,45 \pm 3,41$ & \\
\hline & 5yılveüzeri & $70,5 \pm 2,12$ & \\
\hline \multirow{2}{*}{$\begin{array}{l}\text { Farklı Kronik Hastalık } \\
\text { Durumu }\end{array}$} & Evet & $67,43 \pm 4,35$ & \multirow{2}{*}{$0,009 *$} \\
\hline & Hayır & $65,14 \pm 5,41$ & \\
\hline \multirow{4}{*}{ Farklı Kronik Hastalık } & Diyabet & $67,27 \pm 3,61$ & \multirow{4}{*}{0,839} \\
\hline & $\mathrm{Kr}$,gastrit & $66,75 \pm 5,73$ & \\
\hline & Hipertansiyon & $67,32 \pm 4,54$ & \\
\hline & Astım & $68,41 \pm 3,2$ & \\
\hline
\end{tabular}

\section{TARTIŞMA}

Bu çalışma kanser hastalarında umutsuzluğun ve manevi bakım algısının incelenmesi amacıyla yapıldı. Çalışmada kanser hastaların BUÖ toplam puan ortalaması 11,63 $\pm 5,34$ olarak saptandı (Tablo 2). Bu çalışma sonucunda hastaların orta düzeyde umutsuzluğa sahip oldukları söylenebilir. Bu çalışmaya benzer şekilde Mystakidou ve ark. ${ }^{[29]}$ (2008) ve Somasundaram ve ark. ${ }^{[30]}$ (2016) palyatif bakım tedavisi alan kanser hastalarıyla yaptıkları çalışmada, hastaların BUÖ puan ortalamasını sırasıyla $9,93 \pm 7,38$ ve $12,37 \pm 7,06$ olarak saptamıştır. Bu çalışmanın aksine Tan ve Karabulutlu'un ${ }^{[31]}$ (2005), Madani ve ark. ${ }^{[32]}$ (2019) ve Nehir ve ark. ${ }^{[33]}$ (2019) kanser hastalarıyla yaptığı çalışmada sırasıyla BUÖ puan ortalaması $6,5 \pm 3,6,5,93 \pm 4,71$ ve $8,20 \pm 6,72$ olarak saptanmıştır. Yıldııım ve ark. ${ }^{[34]}$ (2009) metastatik ve terminal dönem kanser hastalığı olmayan hastalarla yaptığı çalışmada da BUÖ puan ortalaması

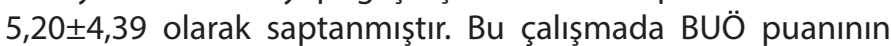
benzer çalışmalara göre yüksek olmasının sebebi örneklemde yer alan bireylerin yaş ortalamasının yüksek olmasından kaynaklı olabilir. Ayrıca hastalar yeterli sosyal destek aldıklarını ifade etmiş olmalarına rağmen; sosyal desteğin depresyon ve umutsuzluk gibi negatif duyguları azatlığı düşünülürse ${ }^{[35]}$ hastaların aldıkları sosyal desteğin yetersiz olduğu söylenebilir. Tablo 2'de, gelecekle ilgili duyguların 3,26 $\pm 1,89$, motivasyon kaybının 4,04 $\pm 2,20$ ve gelecekle ilgili beklentiler puan ortalamasının $3,47 \pm 1,46$ olduğu görülmektedir. Bizim çalışmamızın aksine Nehir ve ark. ${ }^{[3]]}$ (2019) kanser hastalarıyla

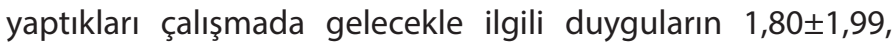
motivasyon kaybının $3,04 \pm 2,83$ ve gelecekle ilgili beklentiler puan ortalamasının $2,67 \pm 1,77$ olduğu saptanmıştır. Bu sonuçlara bakıldığında bu çalışmadaki hastaların daha umutsuz olduğu görülmektedir.

Bu çalışmada yaş ile "gelecek ile ilgili duygular" alt boyut puanı arasında anlamlı bir ilişki olduğu görüldü $(r=0,183$ ve $p=0,041$ ); ve buna göre bireylerin yaşı arttıkça gelecek ile ilgili duygularının da arttığı söylenebilir. Bu çalışma ile benzer şekilde Chan ve [i $^{[36]}$ (2002) yaşla birlikte umutsuzluğun artığını saptamıştır. Ancak bu çalışmanın aksine yapılan bazı çalışmalarda ise yaş ile BUÖ puanı arasında önemli negatif bir iliş̧ki olduğu ve yaş artıkça umutsuzluğun azaldığı saptanmıştır. [37-39] Ayrıca çalışmamızda yaş ile BUÖ toplam puanı, "motivasyon kaybı" ve "gelecek ile ilgili beklentiler" alt boyut puan ortalaması arasında önemli bir ilişki olmadığı saptandı (Tablo 2; $p>0,05)$. Bizim çalışmamıza benzer şekilde Yıldııım ve $\operatorname{ark.}^{\left[{ }^{[34]}\right.}$ (2009) ve Öztunç ve ark..$^{[35]}$ (2013) yaptığı çalışmada da yaş ile BUÖ puanı arasında önemli bir fark bulunmamıştır. Bu araştırmada medeni durum ile BUÖ toplam puanı, "gelecek ile ilgili duygular" ve "gelecek ile ilgili beklentiler" alt boyut puan ortalaması arasında önemli bir ilişki olduğu ve bekar bireylerin daha umutlu olduğu saptandı. Bu sonuca bekar hastaların aile sorumluluklarının vegelecekleilişkili kaygılarının daha az olması gibi durumlarından kaynaklanabileceği düşünülmektedir. Bu araştırmada yalnız yaşamayanların yalnız yaşayanlara göre "gelecek ile ilgili duygular" alt boyut puan ortalaması daha düşük bulunup daha fazla umutlu oldukları 
saptandı. Bener ve ark. ${ }^{[39]}$ (2017), Duggleby ve ark. ${ }^{[40]}$ (2013) ve Rustoen ve Wiklund ${ }^{[41]}$ (2000) çalışmasında da bu çalışma bulgusuna benzer sonuçlar saptanmıştır. Yapılan çalışmalarda sosyal desteğin kanser tanısı alan bireylerin umudu üzerinde önemli bir faktör olduğu ve sosyal destek ile umut arasında pozitif bir ilişki olduğu görülmüştür. ${ }^{[33,42,43]}$ Ancak bu çalışmada sosyal desteği olanların olmayanlara göre daha fazla umutsuzluk içinde olduğu saptandı. Literatürün aksine bu çalışmada elde edilen bulgulara göre, sosyal desteklerinin yeterli düzeyde olmadığını göstermektedir.

Bu çalışmada ailesinde başka kanser hastasının olma durumu ile "gelecek ile ilgili beklentiler" alt boyut puan ortalaması arasında önemli bir ilişki olduğu ve ailesinde başka kanser hastası olan hastaların daha umutsuz olduğu saptandı. Bu bireyler ailesinde kanser vakasını ve sürecini yaşadıklarından dolayı geleceğe umutlu bakmayabilirler.

Bu araştırmada hastalık süresi ile BUÖ toplam puanı ve"gelecek ile ilgili beklentiler" alt boyut puan ortalaması arasında önemli bir ilişki olduğu ve hastalık süresi artıkça hastaların daha umutsuz olduğu saptandı. Gümüş ve ark. ${ }^{[44]}$ (2011) yaptığı çalışmada, kronik hastalığın doğası olarak uzun süren tedavi süreci ve yan etkilerden dolayı hastalarda pozitif algılarda azalmaya ve umutsuzluğa sebep olduğu belirtilmektedir.Bu sonuç çalışmamızın bulgusunu destekler niteliktedir. Bizim çalışmamızın aksine Fadıloğlu ve ark. ${ }^{[35]}$ (2006) meme kanserli hastalarla yaptığı çalışmada, Vellone ve ark. ${ }^{[45]}$ (2006), Aslan ve ark. ${ }^{[46]}$ (2007) Öztunç ve ark. ${ }^{[47]}$ (2013) kanser hastalarıyla yaptıkları çalışmada hastalık süresi ile umutsuzluk arasında bir ilişki olmadığı bulunmuştur. Literatürde kanser hastalarının hastalık sürecinin her aşamasında çeşitli ve karmaşık davranışsal duygusal ve ruhsal tepkileri gösterebildikleri bulunmuştur. ${ }^{[48,49]}$ Bu sonuç; çalışmadaki hastaların yaşadıkları bölgenin sosyokültürel yapısının farklı olmasından kaynaklı olabilir.

Çalışmada kanser hastalarında, başka bir kronik hastalığın olma durumuna göre BUÖ toplam puanı, gelecek ile ilgili duygular, motivasyon kaybı ve gelecek ile ilgili beklentiler alt boyut puan ortalaması daha yüksek bulunup hastaların daha umutsuz olduğu saptandı. Ercan'ın ${ }^{[50]}$ (2016) yaptığı çalışmada farklı bir kronik hastalığın olma durumunun umutsuzluğu artırdığını bildirilmektedir. Farklı çalışmalarda da başka kronik hastalığı olan bireylerin motivasyon kayıplarının daha fazla olduğu tespit edilmiştir. ${ }^{[51,52]}$ Birden fazla kronik hastalık durumunda, bireyler farklı semptomlarla baş etmek, farklı tedavileri sürdürmek ve fonksiyonel sınırlılıklar oluşturması nedeniyle kişilerde umutsuzluk, gelecek ile ilgili duygu ve beklentileri azalttığı ve motivasyon kaybı oluşturabileceği düşünülmektedir.

Çalışmada kanser hastaların MMBDÖ toplam puan ortalaması $66,54 \pm 4,90$ olarak saptandı (Tablo 2). Hastaların yüksek düzeyde maneviyat ve manevi bakıma sahip oldukları söylenebilir. Doğan'ın ${ }^{[53]}$ (2018) kronik hastalığı olmayan yaşlı bireylerle yaptığı çalışmada MMBDÖ toplam puan ortalaması $52,07 \pm 9,81$ olduğu ve orta düzeyde maneviyat ve manevi bakım sergilendiği görülmektedir. Yazgan'ın ${ }^{[54]}$ (2014) kanser hastası olan ve olmayan bireylerle yaptığı çalışmada; kanser hastası olan bireylerin dini tutumunun kanser hastası olmayan bireylerden daha olumlu olduğu bildirmiştir.Üstündağ'ın ${ }^{[55]}$ (2013) kanser hastalarında yaptığı çalışmada; bireylerin \%92,2'sinin şifa bulmak için kültürel ve dini uygulamalara başvurduğunu ifade etmiştir. Literatürde kanser hastalarının dini uygulamaları fazla kullandığını belirten farklı çalışmalar da yer almaktadır. ${ }^{[56,57]}$ Daştan ve Buzlu'nun ${ }^{[19]}$ (2010) meme kanserli hastalar üzerinde manevi bakımı tartıştıkları derlemelerinde, manevi bakımın kanser hastaları üzerinde yaşam kalitesini arttırıcı ve umut duygularını geliştirici etkisinin yüksek olduğu sonucuna varmışlardır.

Çalışmamızda bekar kanser hastaların maneviyat ve manevi bakım toplam puan ortalamasının evlilere göre daha yüksek olduğu belirlendi (Tablo 4, p:0,016). Bizim çalışmamızın aksine Doğan'ın[53] (2018) kronik hastalığı olmayan yaşlı bireylerle, Şahin ve Özdemir'in ${ }^{[58]}$ (2016) hemşirelerle ve Jadidi ve ark. [59] (2015) yaşlı bireylerle yaptıkları çalışmada evli bireylerin maneviyat ve manevi bakım toplam puan ortalamasının bekarlara göre yüksek olduğu saptanmıştır. Bu sonuç; hastaların kendi dünya görüşü ve maneviyat ve manevi bakım kavramlarını yorumlarına bağlı subjektif bir kavram olmasıyla açıklanabilir. ${ }^{[28]}$

Çalışmamızda ailesinde başka kanser hastası olanların maneviyat ve manevi bakım toplam puan ortalamasının ailesinde başka kanser hastası olmayanlara göre daha yüksek olduğu belirlendi (Tablo 4, p:0,021). Yapılan bir çalışmada kanserli hastalara bakım verenlerin manevi duygularının kuvvetli olduğu gösterilmiştir. ${ }^{[60,61]}$ Ailesinde kanser hastası olan bireylerin yaşamlarında oluşan olumsuzluklar ve artan stres ile baş etmek için manevi uygulamalara yöneldikleri böylece maneviyatlarının iyi düzeyde olduğu bildirilmiştir. ${ }^{[62]}$ Ayrıca maneviyat, ölüm korkusu gibi büyük sorunlarla mücadele ederken bireylere yaşam umudu vererek ve hayattan anlam çıkarmalarına yardımcı olmakta; ölümün ve yaşamın sırrını anlama becerisi kazandırmaktadır. ${ }^{[33]} \mathrm{Bu}$ sonuç; bireylerin yakınlarının sağlık sorunlarından etkilendiği bundan dolayı manevi boyuta daha fazla önem verdikleri ve yakınlarının manevi gereksinimlerine duyarlı oldukları düşünülebilir.

Çalışmamızda başka bir kronik hastalığı olanların maneviyat ve manevi bakım toplam puan ortalamasının başka bir kronik hastalığı olmayanlara göre daha yüksek olduğu belirlendi (Tablo 4, p:0,009). Wallace ve O'Shea ${ }^{[63]}$ (2007) maneviyatın kronik hastalıklarla başa çıkmaya yardımcı olduğunu ifade etmiştir. Modjarrad ${ }^{[64]}$ (2004) maneviyatın, hastalıkları giderdiği ve zorluklarla baş etmeyi kolaylaştırdığını bildirmiştir. Grant ${ }^{[65]}$ (2004) ise; maneviyatın bireylere iç huzur ve başa çıkma enerjisi verdiğini, kendini tanımayı kolaylaştırdığını ve fiziksel rahatlama sağlamaya yardımcı olduğunu vurgulamıştır. Bireylerin sahip oldukları dini inançları ve kültürel değerleri hastalıkile baş etme mekanizmasında kullandıkları söylenebilir. Çalışmamızda kanser hastaların maneviyat ve manevi bakım algılarıyla umutsuzluk düzeyleri arasında istatistiksel olarak önemli bir ilişki olmadığı sonucuna varıldı $(p>0,05)$. Bizim çalışmamızın aksine literatürde yapılan çalışmalarda maneviyat 
ve umutsuzluk arasında ters bir ilişki olduğu yani maneviyat arttıkça umutsuzluğun azaldığı belirtilmektedir. ${ }^{[19,53,66-68]}$ Bizim çalışmamızdaki bu farklılığın sebebi hastaların maneviyat ve manevi bakım algıları yüksek olsa da hastalıkla baş etme yöntemi olarak maneviyatı yeteri kadar kullanamamalarından ve bu konuda yeterli destek görmemelerinden kaynaklandığı ve buna bağlı umutsuzluk düzeylerinin yüksek olduğu söylenebilir. Literatürde akıl, beden ve ruh arasında uyumsuzluğun yaşandığı kriz zamanlarında, hemşirelerin bireyin kaygılarını dinleme, empati yapma gibi manevi bakım girişimlerinde bulunmasının hastaların ağrı ve anksiyetesini azalttığı, ${ }^{[69-71]}$ fizyolojik, psikolojik ve mental rahatlığı ve iletişimi artırdığı, iyileşme sürecini olumlu etkilediği belirlenmiştir. ${ }^{[71,72]}$ Bu nedenle hemşirelerin bireyin kendini güçlü hissetmesine, hastalıklarla ve getirdiği sorunlarla manevi baş etme stratejileri geliştirmesine ve bu stratejileri uygulamasına destek olması sağlanabilir.

\section{SONUÇ}

Sonuç olarak; Çalışmamızdaki kanser hastaların orta düzeyde umutsuzluğa sahip olduğu belirlendi. Hastaların medeni durumu, biriyle yaşama durumu, ailesinde başka kanser hastasının olma durumu, başka bir kronik hastalığın varlığı, teşhis edilme zamanı ve sosyal desteğin olma durumu ile umutsuzluk düzeyi arasında istatistiksel olarak önemli fark olduğu tespit edildi. Hastaların maneviyat ve manevi bakım algıların yüksek düzeyde olduğu bulundu. Ailesinde başka kanser hastasının olma durumu ve başka bir kronik hastalığın varlığı ile maneviyat ve manevi bakım düzeyi arasında istatistiksel olarak önemli fark olduğu tespit edildi. Ayrıca çalışmamızda hastaların maneviyat ve manevi bakım algılarıyla umutsuzluk düzeyleri arasında istatistiksel olarak önemli bir ilişki olmadığı saptandı.

Bu sonuçlar doğrultusunda,

- Bakım verilen bireylerin; maneviyat algısını etkileyen faktörler göz önünde bulundurması önerilmektedir.

- Hemşirelik girişimleri bireylerin maneviyatına gereken önemi verecek şekilde planlanmalıdır.

- Hemşirenin başkalarının manevi gereksinimlerini fark edebilmesi için, öncelikle kendi maneviyatını keşfetmesi gerektiği göz önüne alındığında bu konuda hizmet içi eğitimler verilerek bilgi, beceri ve yaklaşımlarının artırılması önerilebilir.

- Hastaların sosyal desteklerinin güçlendirilmesinin sağlanması önerilebilir.

- Çalışmanın daha geniş ve farklı örneklem gruplarıyla yapılması önerilebilir.

Araştırmanın Sınırlııkları: Araştırma, Van ilinde onkoloji kliniğinde yatan hastalar ile sınırlıdır ve bu araştırmanın sonuçları çalışmada yer alan grubun dışındaki hastalara genellenemez.

\section{ETIK BEYANLAR}

Etik Kurul Onayı: Araştırma Van Yüzüncü yıl Üniversitesi Klinik Araştırmalar Etik Kurulu'ndan 15/05/2019 tarih 2019/05-01 sayı ile onay ve araştırmanın gerçekleştirildiği kurumdan yazııı izin alındı.

Aydınlatılmış Onam: Bu çalışmaya katılan hasta(lar)dan yazıı onam alınmıştır.

Hakem Değerlendirme Süreci: Harici çift kör hakem değerlendirmesi.

Çıkar Çatışması Durumu: Yazarlar bu çalışmada herhangi bir çıkara dayalı ilişki olmadığını beyan etmişlerdir.

Finansal Destek: Yazarlar bu çalışmada finansal destek almadıklarını beyan etmişlerdir.

Yazar Katkıları: Yazarların tümü; makalenin tasarımına, yürütülmesine, analizine katıldığını ve son sürümünü onayladıklarını beyan etmişlerdir.

\section{KAYNAKLAR}

1. Şentürk S, Bıçak D, Akça D. Kanserli hasta yakınlarının yaşadıkları sorunlar ve hemşirelik yaklaşımı. Sağlık Akademisyenleri Derg 2018;5:35-9.

2. Karabulutlu EY, Karaman S. Kanser hastalarında hastalık algısının değerlendirilmesi. Sağlık Bilimleri ve Meslekleri Derg 2015;2(3):271-84.

3. Karabuğa $\mathrm{H}$, Pinar R. Kanserli hastalara bakım veren aile üyelerinin yaşam kalitesi ve yaşam kalitesini etkileyen faktörlerin değerlendirilmesi. Turkish Journal of Research \& Development in Nursing 2013;15(2):1-16.

4. Tuncay T. Genç Kanser Hastalarinin Hastalik Anlatilarinin güçlendirme Yaklaşimi temelinde analizi. Toplum ve Sosyal Hizmet 2009;20(2):69-88.

5. Şentürk V, Yaylı M, Civelek A. Bir hastanın güncesi: kemik iliği nakli yapılan hastalara psikososyal yaklaşım. Kriz Derg 2012;12(1):55-65.

6. Öz F. Ümit ve Ümitsizlik İçinde: Öz F (ed). Sağlık Alanında Temel Kavramlar, 2 Baskı. Ankara, Mattek matbaacılık 2010;189.

7. Fadıloğlu Ç, Cantilav Ş, Yıldırım YK, Tokem Y. Meme kanserli kadınlarda umutsuzluk düzeyi ve baş etme davranışları arasındaki ilişki. Ege Üniversitesi Hemşirelik Yüksek Okulu Dergisi 2006;22:147-60.

8. Kelleci M. Kanser hastalarının umudunun geliştirilmesine yönelik hemşirelik girişimleri. Anadolu Psikiyatri Dergisi 2005;6(1):41-7.

9. Baljani E, Kazemi M, Amanpour E, Tizfahm T. The relationship between religion, spiritual well-being, hope and quality of life in patients with cancer. Basic \& Clinical Cancer Research 2014;6:28-36.

10. Rawdin B, Evans C, Rabow MW. The relationships among hope, pain, psychological distress, and spiritual well-being in oncology outpatients. J Palliat Med 2013;16:167-72.

11. Wakiuchi J, Marchi JA, Norvila LS, Marcon SS, Sales CA. Hope of cancer patients undergoing chemotherapy. Acta Paul Enferm 2015;28:202-8.

12. Kılıç DD. Onkoloji hastalarında manevi iyiliğin umut ve depresyonla ilişkisi. Halk Sağlığı Hemşireliği Anabilim Dalı, Doktora Tezi, Erzurum, Atatürk Üniversitesi, 2018.

13. Bayındır SK, Biçer S. Holistik Hemşirelik Bakımı. İzmir Katip Çelebi Üniversitesi Sağlık Bilimleri Fakültesi Dergisi 2019;4(1):25-9.

14. Hutchinson M. Healing the whole person: the spiritual dimension of holistic care. 1997; URL: http://Members.Tripod.Com/ Marg_Hutchison/ Nurse-4.Html. Erişim Tarihi: 29 Aralık 2019.

15. Türk Dil Kurumu. http://www.tdk.gov.tr. Erişim Tarihi: 16 Eylül 2019.

16. McSherry W. Education issues surrounding the teaching of spirituality. Nursing Standard (through 2013), 2000;14(42):40-3

17. Pilger C, Santos ROP, Lentsck MH, Marques S, Kusumota L. Spiritual wellbeing and quality of life of older adults in hemodialysis. Rev Bras Enferm, 2017,70:689-96. 
18. Srivastava J, Shukla H, Kaushik S, Tewari M. Assessment of distress (depression, anxiety and stress) in Indian women with breast cancer: Predictive role of spiritual well being. Annals of Oncology 2016;27:161-2.

19. Daştan NB, Buzlu S. Meme kanseri hastalarında maneviyatın etkileri ve manevi bakım. Maltepe Üniversitesi Hemşirelik Bilim ve Sanatı Dergisi 2010;3(1):73-8.

20. Kavak F, Mankan T, Polat H, Sarıtaş S, Sarıtaş S. Hemşirelerin manevi bakıma ilişkin görüşleri. İnönü Üniversitesi Sağlık Bilimleri Dergisi 2014;3(1):21-4.

21. Johnson KS, Tulsky JA, Hays JC, et al. Which domains of spirituality are associated with anxiety and depression in patients with advanced illness? J Gen Intern Med 2011;26(7):751-8.

22. Albayrak A, Kurt E. Meme kanserli hastalarda ağrı ve uzuv kaybına (mastektomi) bağlı depresyon düzeylerinin yaşam kalitesi ve dindarlik ile ilişkisi. Dokuz Eylül Ünivesitesi İlahiyat Fakültesi Dergisi 2016;41-81.

23. Aslan Ö, Sekmen K, Kömürcü Ş, Özet A. Kanserli hastalarda umut. CÜ Hemşirelik Yüksekokulu Dergisi 2007;11:18-24.

24. Beck AT, Weissman A, Lester D, Trexler L. The measurement of pessimism: the hopelessness scale. J Consult Clin Psychol 1974;42(6):861.

25. Seber G, Dilbaz N, Kaptanoğlu C, Tekin D. Umutsuzluk ölçeği: geçerlilik ve güvenirliği. Kriz Dergisi 1993;1(3):139-42.

26. Durak A, Palabiyikoğlu R. beck umutsuzluk ölçeği geçerlilik çalişmasi. Kriz Dergisi 1994;2(2):311-9.

27. McSherry W, Draper P, Kendrick D. The construct validity of a rating scale designed to assess spirituality and spiritual care. Int J Nurs Stud 2002;39(7):723-34.

28. Ergül Ş, Bayık T. ;Maneviyat ve manevi bakım dereceleme ölçeği'nin türkçe formu'nun geçerlik ve güvenirliği. Ege Üniversitesi Hemşirelik Yüksekokulu Dergisi 2007;23(1):75-87.

29. Mystakidou K, Parpa E, Tsilika E, et al. Preparatory grief, psychological distress and hopelessness in advanced cancer patients. Eur J Cancer Care 2008;17(2):145-51.

30. Somasundaram RO, Devamani KA. A comparative study on resilience, perceived social support and hopelessness among cancer patients treated with curative and palliative care. Indian j Palliat Care 2016;22(2):135-40

31. Tan M, Karabulutlu E. Social support and hopelessness in Turkish patients with cancer. Cancer Nurs 2005;28(3):236.

32. Madani H, Pourmemari M, Moghimi M, Rashvand F. Hopelessness, perceive social support and their relationship in iranian patients with cancer. Asia-Pac j Oncol Nurs 2018;5(3):314-9.

33. Nehir S, Tavşanli NG, Özdemir Ç, Akyol TA. Determination of hopelessness and the perception of illness in cancer. OMEGA-Journal of Death and Dying 2019;79:115-31

34. Yildirim Y, Sertoz OO, Uyar M, Fadiloglu C, Uslu R. Hopelessness in Turkish cancer inpatients: the relation of hopelessness with psychological and disease-related outcomes. Eur J Oncol Nurs 2009;13(2):81-6.

35. Oztunc G, Yesil P, Paydas S, Erdogan S. Social support and hopelessness in patients with breast cancer. Asian Pac J Cancer Prev 2013;14(1):571-8.

36. Chang L-C, Li I-C. The correlation between perceptions of control and hope status in home-based cancer patients. J Nurs Res 2002;10(1):73-82.

37. Benzein EG, Berg AC. The level of and relation between hope, hopelessness and fatigue in patients and family members in palliative care. Palliat Med 2005;19(3):234-40.

38. Okano $\mathrm{Y}$, Okamura $\mathrm{H}$, Watanabe $\mathrm{T}$, et al. Mental adjustment to first recurrence and correlated factors in patients with breast cancer. Breast Cancer Res Treat 2001;67(3):255-62.

39. Rustøen T, Wiklund I, Hanestad BR, Moum T. Nursing intervention to increase hope and quality of life in newly diagnosed cancer patients. Cancer Nurs 1998;21:235-45.

40. Duggleby W, Ghosh S, Cooper D, Dwernychuk L. Hope in newly diagnosed cancer patients. J Pain Symptom Management 2013;46(5):661-70.

41. Bener A, Alsulaiman R, Doodson L, Agathangelou T. Depression, hopelessness and social support among breast cancer patients: in highly endogamous population. Asian Pac J Cancer Prev 2017;18(7):1889-96.
42. Pehlivan S, Ovayolu O, Ovayolu N, Sevinc A, Camci C. Relationship between hopelessness, loneliness, and perceived social support from family in Turkish patients with cancer. Supportive Care in Cancer 2012;20(4):733-9.

43. Kavradım ST, Özer ZC. Kanser tanısı alan hastalarda umut. Psikiyatride Güncel Yaklaşımlar 2014;6(2):154-64.

44. Gumus AB, Cam O, Malak AT. Relationships between psychosocial adjustment and hopelessness in women with breast cancer. Asian Pac J Cancer Prev 2011;12(2):433-8.

45. Vellone E, Rega ML, Galletti C, Cohen MZ. Hope and related variables in Italian cancer patients. Cancer Nurs 2006;29(5):356-366.

46. Fadıloğlu Ç, Cantilav Ş, Yıldırım Y, Tokem Y. Meme kanserli kadınlarda umutsuzluk düzeyi ve baş etme davranışları arasındaki ilişki. Ege Üniv Hemşirelik Yüksekokulu Derg 2006;22:147-60.

47. Aslan Ö, Sekmen K, Kömürcü Ş. Hope in cancer patients. J Nurs College 2007;11(2):18-24.

48. Çam O, Saka Ş, Gümüş AB. Meme kanserli hastaların psikososyal uyumların etkileyen faktörlerin incelenmesi. Meme Saglıgı Dergisi 2009;5(2):73-81.

49. Özkan S. PsikiyatrikTıp: Konsültasyon - Liyezon Psikiyatrisi. Baskı. İstanbul, Roche Müstahzarları Sanayi A.Ş. 1993.

50. Ercan F. Hemodiyaliz uygulanan hastaların umutsuzluk ve yaşam kalitesi düzeylerinin belirlenmesi. Gazi Üniversitesi Sağlık Bilimleri Enstitüsü, Ankara, Yüksek Lisans Tezi, 2016.

51. Babur S. Hemodiyaliz Hastalarının Manevi Yönelimleri ile Umutsuzluk Düzeyleri Arasındaki İlişki. Ondokuz Mayıs Üniversitesi Sağlık Bilimleri Enstitüsü. Samsun. Yüksek Lisans Tezi, 2019.

52. Yüksel Ş. Onkolojik cerrahi geçiren hastaların spiritualite ve umut durumlarının belirlenmesi. Hasan Kalyoncu Üniversitesi Sağlık Bilimleri Enstitüsü. Samsun. Yüksek Lisans Tezi, 2019.

53. Doğan S. Kronik Hastalığı Olmayan Yaşlı Bireylerde Manevi Bakım, Yaşam Kalitesi Ve Aradaki İlişkinin Değerlendirilmesi. Hemşirelik Anabilim Dalı. Kars: Kafkas Üniversitesi 2018.

54. Yazgan ED. Kemoterapi Alan Kanserli Hastalarında Dini İnanç ve Maneviyatın Depresyon Düzeyi ve Yaşam Kalitesine Etkisinin Belirlenmesi. Ankara Üniversitesi, Sağlık Bilimler Enstitüsü, Yüksek lisans Tezi, Ankara, 2014.

55. Üstündağ S. (2013). Kemoterapi alan kanser hastalarının semptom yönetiminde kullandıkları tamamlayıcı tedavi yaklaşımlarının yaşam kalitesine etkisi. Ankara Üniversitesi Sağlık Bilimleri Enstitüsü, Yüksek Lisans Tezi, Ankara, 2013.

56. Nazik E, Nazik H, Api E. Complementary and alternative medicine use by gynecologic oncology patients in Turkey. Asian Pacific Journal of Cancer Prevention 2012;13:21-5

57. Uçan Ö, Pehlivan S, Ovayolu N. The use of complementary and alternative therapies in cancer patients. American Journal of Clinical Oncology 2008:31:589-94.

58. Şahin ZA, Özdemir FK. Spirituality and spiritual care: a descriptive survey of nursing practices in Turkey. Contemporary nurse 2016;52(4):454-61.

59. Jadidi A, Farahaninia M, Janmahamadi S, Haghani $H$. The relationship between spiritual well-being and quality of life among elderly people. Holistic Nursing Practıce 2015;29(3):128-35.

60. Fadıloğlu Ç. Kanserli hastaya bakım veren aile üyelerinin hastalıkla başa çıkma davranışlarının incelenmesi. Hemşirelik Yüksek Okulu Dergisi 1996;12(1):21-34.

61. Reel B. Effect of counseling on quality of life for individuals with cancer and their families. Cancer Nursing 1994;17(2):101-2.

62. Yıldız E, Dedeli Ö, Pakyüz SÇ. Kanser hastalarına bakım veren aile üyelerinin bakım yükü ve yaşam kalitesinin incelenmesi. Hemşirelikte Eğitim Ve Araştirma Dergisi 2016;13(3):216-25. 
63. Wallace M, O'Shea E. Perceptions of spirituality and spiritual care among older nursing home residents at the end of life. Holistic nursing practice 2007;21(6):285-9.

64. Modjarrad K. Medicine and spirituality, Student JAMA 2000;291(23):2880.

65. Grant D. Spiritual interventions: how, when and why nurses use them. Holistic Nursing Practice 2004;18(1);36-4.

66. Cotton SP, Levine EG, Fitzpatrick CM, Dold KH, Targ E. Exploring the relationships among spiritual well-being, quality of life, and psychological adjustment in women with breast cancer. Psycho-Oncology: Journal of the Psychological, Social and Behavioral Dimensions of Cancer 1999;8(5):429-38

67. Culliford L. Spirituality and clinical care: Spiritual values and skills are increasingly recognised as necessary aspects of clinical care. 2002.

68. Levine EG, Targ E. Spiritual correlates of functional well-being in women with breast cancer. Integr Cancer Ther 2002;1(2):166-74.

69. Carpenter K, Girvin L, Kitner W, Ruth-Sahd LA. Spirituality: a dimension of holistic critical care nursing. Dimens Crit Care Nurs 2008;27(1):16-20.

70. Pedrão RdB, Beresin R. Nursing and spirituality. Einstein (São Paulo) 2010;8(1):86-91.

71. Çınar F, Eti Aslan F. Spiritüalizm ve hemşirelik: Yoğun bakım hastalarında spiritüel bakımın önemi. J Academic Res Nurs 2017;3(1):37-42.

72. Wong KF, Lee LY, Lee JK. Hong Kong enrolled nurses' perceptions of spirituality and spiritual care. Int Nurs Rev 2008;55(3):333-40. 